\title{
Prospek Hukum Islam dalam Era Liberalisasi Perdagangan Internasional
}

\author{
Oleh : Abdur Rachim
}

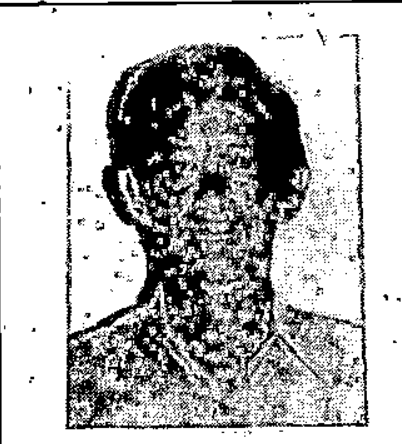

Pendahuluan"

Demam liberalisasi dalam dunia perdagàngan kembali kini menyerang para ahli hukum sebagai alternatif dalam menentukan norma dalam mewrijudkan. liberalisasi perdagangan internasional.

Agaknya logika Adam Smith dimunculkan kembali karena liberalisasi dalam perdagangan intemasional dirasakan akan membawa kesejahteraan bagi negara secara menyeluruh.

Prediksi teoritik tentang trend perdagangan intemasional isinya mengarah ke arus liberalisasi intemasional. Itulah sebabnya maka pada seminar sehari ini kita adakan kajian sampai seberapa jauh kita sudah mempersiapkan peran hukum dalam liberalisasi perdagangan internasional itú.

Tidak terlupakan pula prospek hukum Islam dalam era liberalisasi perdagangan intemasional, sebagai tinjauán kedepan; bagaimana peran hukum yang digali dari Al Quran dan As Sunnah dan dikembangkan dengan daya ijtihad itu dapat mengimbangi perkembangan fikiran manusia dalam era liberalisasi perdagangan intemasional.

Liberalisasi Perdagangan Inter-nasional Kemajuan ilmu pengetahuan dan teknologi memberikan dampak kemajuan dalam setiap aspek kehidupan manusia dan memberikan kemudahan dalam komunikasi yang menyebabkan arus globalisasi dalam setiap struktur kehidupan, tak dapat dibendung lagi.

Maka seharusnyalah, setiap kemajuan dalam aktivitas manusia,,${ }_{,}$, 
dipersiapkan pula perangkat noma hukum yang diharapkan dapat memelihara keseimbangan dari kegiatan itu.

Demikian pula apabila dalam dunia ekonomi sekarang ini orang melirik pada liberalisasi perdagangan internasional, maka para ahli hukum dapat pula memprediksikan keseimbangan antara penyimpangan dan keharusan yang dipatuhi.

Sebelum kita melangkah lcbih jauh, perlu kita ketahui bahwa liberalisasi perdagangan yang dicendenungi oleh Adam Smith itu timbul pada saat dia mempelajari ekonomi secara sistematik, tctapi jangan lupa bahwa pada saat itu industrialisasi mencapai kemajuan dan produktivitaspun melimpah ruah maka timbullah semboyan "lesser fair lesser passer", yang menjadi. dasar tinibulnya arus liberalisasi itu.

Memang dalam suatu negara yang maju, yang sudah mampu memproduksi hasil produksi berlimpah-limpah, lebih disukai liberalisasi perdagangan, tctapi bagi negara-negara yang sedang membangun, liberalisasi perdagangan akan menjadi malapetaka, terutama bagi negara yang sedang membangun industrinya, sebab negara itu baru memproduksikan hasil produksi secara terbatas, maka apabila mendapat saingan dari negara yang sudah maju, apakah persaingan itu tidak menjadi malapetaka? sebab negara yang sedang membangun industrinya memerlukan proteksi.

Maka liberalisasi perdagangan . internasional itu dapat disetujui pada situasi dan kondisi yang berimbang, pada saat kemajuan ekonomi telah merata disetiap negara. Tanpa memperhatikan situasi dan kondisi, maka liberalisasi perdagangan internasional itu akan memberikan manfaat bagi bcberapa pihak, tetapi akan-membuat petaka dibcberapa pihak yang lain.

Itulah scbabnya maka pemikiran yang dapat memelihara keseimbangan dalam kehidupan ekonomi sangat diperlukan. Pemikiran antara manfaat dan mafsadah, yang dápat dituangkan dalam perangkat norma yang dapat dipatuhi, schingga arus liberalisasi perdagangan internasional itu benar-benar dapat bermanfaat bagi peningkatan harkat manusia.

\section{Prospek Hukum Islam}

Hukum Islam mempunyai lima tujuan, yaitu memelihara jiwa, akal, harta, keturunan dan aturan agama. Pada. prinsipnya hukum Islam bertujuan untuk menghantarkan manusia agar mampu memelihara kelangsungan hidupnya.

Seperti kita ketahui bahwa hukum Islam ialah seperangkat hukum yang diyakini datang dari Pencipta alam semesta diperuntukan pada manusia agar dapat mencapai kebahagiaan hidupnya di dunia dan di akhirat. Aturan hukum itu memberikan bimbingan ke jalan yang benar dan maslahah, memberi dorongan agar manusia manpu melaksanakannya, serta membangun perhatian agar manusia menghindari kejahatan dan mafsadah. Aturan hukum itu tidak menawarkan sesuatu terkecuali karena terdapat kemaslahatan yang realistik, baik kemaslahatan dunia maupun akhirat dan tidak pula mencegah terkecuali karena terdapat kejahatan dan jalan-jalan yang 
membawa mafsadah. ${ }^{1}$

Setiap aturan hukumnya dapat dipelajari adanya hikmah kemaslahatannya secara singkat atau. memerlukan waktu, hingga manusiamencapai tingkatpemikiran. untuk mencemanya.

Hukum.Islam ditujukan untuk umat manusia secara umum, tidak diturunkan khusus untuk sekelompok manusia dan bersifat abadi, aturan hukumnya dapat diterapkan untuk sepanjang waktu sejak diturunkan hingga berakhimya tuntutan. ${ }^{2}$

Keuniversalannya ditentukan oleh firman Allah dalam Al Qur'an yang menyatakan bahwa keutusan Muhammad itu sebagai rahmat untuk seluruh alam. ${ }^{3}$

Disamping itukeuniversalan syari'at Islam dapat dipelajari dari struktur hukumnya yang disamping tersusun dari dalil-dalil yang qath'i juga terdapat dalildalil yang dhanni.

Dalil yảng qath'i mengatur secara pasti, tidak tergoyahkan akan adanya perubahan zaman. Dalil yang qath'i itu mengatur prinsip-prinsip hukum seperti ketentuan bahwa perdagangan itu diatur atas dasar suka sama suka.

Dalil yang dhanni mengatur secara elastis dan dapat diinterpretasi secara kenyal sehingga dapat mengikuti perkembangan zaman. Dalam hal ini para ahli hukum mempunyai keluasan mengatur ketentuan hukum secara elastis, berimbang dengan situasi dan kondisi, yang melingkupi kasus yang terjadi, seperti ketentuan hukuni jual beli yang kualitasnya belum dapat diukur dengan alat pengukur. Selama kualitas tersebut telah dapat ditentukan dengan.. ukuran yang pasti maka laranganpun hilang dengan sendirinya.

Disamping itu aturan hukum Ịlam ada yang bersifat global (ijmali) dan ada pula yang bersifat terperinci (tafsili). Maka menghadapi kemungkinan terjadinya perubahan hukum karena terjadinya perkembangan fikiran ada beberapa prinsip yang patut diperhatikan:

1. Hendaknya hukum yang akanditerapkan itu bersesuaian dengan jiwa syara' yang dilandaskan pada kaidah-kaidah yang menyeluruh dan prinsipnya yang asasi.

2. Hendaknyahukum yang akan diterapkan itu tidak bertentangan dengan dalil yang terperinci yang diterapkan sebagai aturan yang menyeluruh bagi manusia, untuk seluruh tempat dan waktu. ${ }^{4}$

Prospek hukum yang kita bicarakan ini menyangkut masalah di luar ibadah mahdah yang pada dasamya pengaturan ketentuan hukumnya pada dasamya boleh 'saja asal tidak dilarang oleh syara's.

Beberapa Prinsip Hukum Islam Tentang Liberalisasi Perdagangan Internasional

Sebagai prospek hukum Islam, menghadapi kemungkinan terjadinya liberalisasi perdagangan internasional seyogyanya kita lihat beberapa prinsip hukum Islam tentang tijarah atau perdagangan yang merupakan jiwa syara' yang tetap harus dipelihara sepanjang zaman.

"Bahwa perdagangan itu hendaknya terjadi atas dasar suka sama suka"6.

Dari ketentuan itu terlihat adanya

1). Abd. Rahman Taj, As Siyasah Asy Syariyyah, hal. 61

2). Ibid.

3). Al Ambiya' 107

4). Abd. Rahman Taj. Op. Cit., hal. 14

5). As Suyuthi. Al Asybah wa an Nadhair. hal 66 . 
kecenderingan hukum Islam terhadap liberalisasi perdagangan internasional, sebab liberalisasi menggambärkan adanya kemerdekaan menentukan adanya kehendak dari kedua belah pihak, tidak terdapat tekanan atau paksaan dari luar untuk menentukan kehendak dari pihakpihak, juga tidak ada pengaruh dari luar untuk menentukan hàrga.

Sudah tentu ketentuan ini berlaku bila kondisi dan situasi tidak menentukan keharusan untuk memelihara keseimbangan. Seperti kemampuan memproduksi' hasil produksi yang tidak berimbang diantara beberapa negara, maka untuk memelihara keseimbangan moneter perlu diperlakukan proteksi dengan tujuan agar keseimbangan dapat dipelihara.

Prinsip yang lain ialah "Băhwa perdagangan harus berjalan secara seimbang antara biaya yang dikorbankan dan keuntungan yang diharapkan".'

Keseimbangan dimaksud juga harus diperhatikan:' dalam merighadapi perdagangan antar negára. Jangan șampai negara yang sudah maju dan dapat memproduksi, mendominasi sedemikian rupa hingga negara yang baru berkembang industrinya gulung tikar. Untuk itulah diperlukan organisasi intemasional yang dapatmemelihara kèseimbangan harga. Jadi liberalisasi perdagangan ini dapat diperlakukan' secara penuh, apabila setiap negara sudah mempunyai kemampuan produktivitas yang berimbang. Ketentuan itu tidak akan dipelihara dengan baik bila tidak didukung oleh húkum yang diakui oleh setiap negara dan dijunjung tinggi olehpemerintah dan masing-masingnegara. Itulah sebabnya, makà masuknya negaránegara dalam cra liberalisasi perdagangan internasional, berarti masuknya negaranegara itu dalam persetujuan terhadap hukum internasional yang dapat mengatur keseimbangan perdagangan intemäsional pula.Prospek hukum Islam terhadapkasuskasus kemanusiaan yang akan terjadi tidak perlu dirisaukan karena Al Qur'an dan $\mathrm{Al}$ Hadits sebagai hukum dasar serta ijtihad sebagai pengembangannya senäntiasa akan mampu menghadapi tuntutan zaman.

Jalan-jalan ijtihad yang telah dirintis oleh para pakar hukum Islam seperti ijma', qiyas, istikhsan, istishhab, istishlah, pendapat shahabat, mura'atul Urfi dan syàri'at umat yang lalu, telah menunjụkkan kecenderungannya dalam penggalian hukum menghadapi kasus yang timbul dalam masyarakat. ${ }^{8}$

Dengan demikian maka prospek hukum Islam terhadap liberalisasi pẹrdagàngan intemasional amat positif apabila masing-masing negara telah mempunyaikemampuari produktivitasyang berimbang. Ákan tetapi bila kemampuan produktivitas tidak seimbang, perlu diciptakan cara agar keseimbangan dapat dikendalikan. Apabila keseimbangan tak dapat dipelihara, maka liberalisasi itưjustru akan menimbulkan' keuntungan disuatu pịak, tetapi bençana dipihak lạin.

Liberalisasi dalam perdagangan intemașional ${ }_{i}$ sama hálnya dengán tangan yang kita miliki, ia bisa menjadi rahmat dan juga bisa menjadi laknat. Ia akan menjadi rahmat bila dikendalikan pada kondisi dan situasi -yang menimbulkan rahmat tetapi akan laknat apabila diarahkan pada situasi dan kondisi yang menimbulkan bencana.

6). An Nisá' 29

7). Al Isra' 29

8). Allal Fasy. Maqashid asy Syari'ah, hal.80 


\section{Penutup}

Demikianlahuraian tentang prospek hukum Islam dalam era liberalisasi perdagangan intemasional yang dapat kami kemukakan, dalam seminar sehari tentang Peran Hukum dalam Liberalisasi Perdagangan Internasional, semoga bermanfafat bagi pengembangan hukum pada umumnya dan pengembangan hukum Islam pada khususnya.

Bila dalam uraian ini terdapat titiktitik kebenaran berarti kebenaran itu datang dari Allahakan tetapi bilaterdapat kesalahan atau kekuarangan tiada lain datangnya dari penyaji yang tidak terlepas dari kesalahan dan kekurangan. Untuk itu kanin molion maaf yang sebesar-besamya.

\section{Daftar Pustaka}

Tafsir AI Qur'an Al Hakim, Muhammad Rasyid Ridlo, Darul Manar Mesir 1367. H.

Muqashid asy Syari'ah al Islamiyah wa Makarimuha 'Allal al Fasy, Al Wahdah Al Arabiah, Darul al' Baidla' 1963 M.

As Siyasah asy Syar'iyyah, Abdur Rachman Taj.

Al Asibah wa an NadhairJalal ad Din as Sayuthy, Sulaiman Mar'iy, Singapura.

Syahrul Musaththarah al Madaniyah, Ma'mun al Kazbiry dan Idris 'Ály' al 'Abdalawy; Beirut, $1971 \mathrm{M}$. 